$\begin{aligned} & \text { Aksaray University } \\ & \text { Journal of Science and Engineering } \\ & \text { e-ISSN: 2587-1277 }\end{aligned}$
http://dergipark.gov.tr/asujse
http://asujse.aksaray.edu.tr

Research Article

\title{
Optical and Electrical Characterization of the Metal Oxide Composites by Hydrothermal Method
}

\author{
Canan Aksu Canbay ${ }^{* *, 1}$, Rekawt Khdir Hamad ${ }^{1}$, Iskender Ozkul ${ }^{2}$ \\ ${ }^{1}$ Firat University, Faculty of Science, Department of Physics, Elazig, Turkey \\ ${ }^{2}$ Mersin University, Engineering Faculty, Department of Mechanical Engineering, 33343, Mersin, Turkey \\ -Received Date: 18 Apr 2019 \\ -Revised Date: 3 May 2019 \\ -Accepted Date: 27 May 2019 \\ -Published Online: 29 June 2019
}

\begin{abstract}
Metal oxide and metallic composites are commonly used in material science. Oxides can perform different physical features by small shift during synthesis. That commonly tends innovative results. In this study copper phthalocyanine based four different composite semiconductor materials fabricated by hydrothermal method. The samples were analyzed by optical and electrical characterization measurements. Reflectance, band gap values and conductivity results obtained and presented as graphics with discussion.
\end{abstract}

\section{Keywords}

Hydrothermal method, optical characterization, electrical characterization.

\section{INTRODUCTION}

Metal oxides are used in many areas and commonly takes research subject in physical and material sciences. The metal elements can get oxide forms easily and that provide wide range different characterization. Many structural combinations can be consisting and it can perform different characteristic feature like an insulator, semiconductor, etc. Thanks by this feature it can be used in sensors, fuel cells, microelectronic components, piezoelectric applications and catalysts. The main challenge is to generate new special properties by developing multi or single particles. In this direction, oxides have many opportunities for innovations [1-4].

\footnotetext{
${ }^{*}$ Corresponding Author: Canan Cansu Canbay, cansu@firat.edu.tr

2017-2019CPublished by Aksaray University

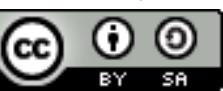


Oxide nanoparticles can perform different physical and chemical features thanks by structural geometric forms like corner density, the surface of edges and limited size of orders. Particle size takes a great role for fundamental of the properties of any material. Primarily crystallographic structure and lattice symmetry and parameters of the cell can be described as main factors. The structural stability is related to internal energy and it can be serious modification regarding with variance of particle size. Bulk oxide can exhibit tough systems but that is associated with particle size. Oxides also can show diversified positive characterizations about mechanical structural by decreasing particle size. However, nanoparticles can be lost the control with other parts at around it in some cases. Eventually, materials can consist more stable in nanoparticle size forms and it can be valid and proved for $\mathrm{TiO}_{2}, \mathrm{VO}_{\mathrm{x}}, \mathrm{Al}_{2} \mathrm{O}_{3}$ or $\mathrm{MoO}_{\mathrm{x}}$ oxides [5-7]. Cell parameters affect the structural size and distortions and some oxides forms observed in nanoparticles like $\mathrm{Fe}_{2} \mathrm{O}_{3}, \mathrm{Al}_{2} \mathrm{O}_{3}, \mathrm{NiO}, \mathrm{MoO}_{3}, \mathrm{CeO}_{2}, \mathrm{ZrO}_{2}$.

Total surface area increase makes harder the neighborhood interactions and affects the environment that causes the disordered structure. This negative positioning can get under control and relax by heat treatment. Interactive nanoparticles on the substrate can because of difficulties and enforce damage to the uniformity of the cell or phase transformation [8-11].

The 'Phthalocyanine' word is consist of from the terms rock oil meaning "naphtha" and the dark blue color name "cyanine". Phthalocyanines have a good candidate for organic semiconductors. Because it has an active layer to adopt organic electronic applications. High thermal and chemical stability is one of the significant properties of Phthalocyanine. Also, Phthalocyanines are generally known as highly stable organic semiconductors. It has advantageous as low-cost fabrication and low toxic values. The phthalocyanine $(\mathrm{Pc})$ polymers that part of organic functional materials was studied many times in literature because of high thermal and chemical stability. That advantageous position has great attractive to researchers [12-14].

Metal Phthalocyanine can be used in many applications. Photo conducting agents, electro-optic implementations, photovoltaic cell elements, photo conducting agents, electrocatalysis, nonlinear optics, and photoelectronic applications, etc. have the opportunity to utilize the metal Phthalocyanines to development individually. Photonic technology and electronic areas need these materials for the multipurpose uses, flexibility in design and ease of application. The readout and high storage lifetimes take great virtue for optical storage applications. The potential uses of Phthalocyanines include sensing elements in electrochromic display devices, chemical sensors, electrocatalysts, photodynamic reagents for fuel cells, photovoltaic cell elements, color photocopying, dyes, conducting polymers solar cells and cardiac pacemakers. 
There are many studies in the fabrication of copper phthalocyanine $(\mathrm{CuPc})$ used applications [15-17]

The purpose of the work is to product composite organic semiconductor materials by using hydrothermal method and to obtain their electrical and optical properties.

\section{EXPERIMENTS AND METHODS}

In this study, two different solutions, sodium hydroxide $\mathrm{NaOH}$ and Zinc acetate $\mathrm{Zn}\left(\mathrm{CH}_{3} \mathrm{COO}\right)_{2}$ were used. Zinc acetate $0.035 \mathrm{gm}$ was dissolved in $20 \mathrm{ml}$ distilled water. Separately sodium hydroxide $0.85 \mathrm{gm}$ was dissolved in distilled water for $20 \mathrm{ml}$. It was put magnetic fish in two of both solution and stirring during $1 \mathrm{~h}$ on the magnetic stirrer. After it was taken the two solutions into 1 cup then put the cup into hydrothermal equipment at $160{ }^{\circ} \mathrm{C}$ and stayed for 12 h. Then it was opened the hydrothermal system and the final solution was transferred to autoclave and heated material dried at $100^{\circ} \mathrm{C}$ for $24 \mathrm{~h}$. Totally four different samples were produced.

Sample 1: $\mathrm{ZnO0.01}$ Mix with $2 \mathrm{ml} \mathrm{C}_{6} \mathrm{H}_{5} \mathrm{Cl}$ inside the cup.

Sample 2: $\mathrm{ZnO} 0.01 \mathrm{Mix}$ with $\mathrm{CuPc} 0.001$ and $2 \mathrm{ml} \mathrm{C}_{6} \mathrm{H}_{5} \mathrm{Cl}$ inside the cup.

Sample 3: $\mathrm{ZnO0.01}$ Mix with $\mathrm{CuPc} 0.002$ and $2 \mathrm{ml} \mathrm{C}_{6} \mathrm{H}_{5} \mathrm{Cl}$ inside the cup.

Sample 4: $\mathrm{ZnO0.01}$ Mix with $\mathrm{CuPc} 0.003$ and $2 \mathrm{ml} \mathrm{C}_{6} \mathrm{H}_{5} \mathrm{Cl}$ inside the cup.

After the dry of the samples, optical and electrical characterizations of the specimens were made by UV-VIS- spectrophotometer and two probe method measurements.

\section{RESULTS AND DISCUSSIONS}

\subsection{Optical Analysis}

The spectral distribution of reflectance $R(\lambda)$ at the ordinary incident for all the sample is displayed in Fig. 1. The light penetrates inside the sample and undergoes absorption inside the sample and the combination of scattering and. Some of the radiation reflects back towards the surface. This reflected radiation has beneficial information due to the higher order of interaction. The reflected radiation is known as Kubelka-Munk (KM) reflectance and is defined by a function. The KM function $F(R)$, could be utilized to near the optical absorbance of the sample from is reflectance and is given by [18].

$\mathrm{F}(\mathrm{R})=\frac{(1-R)^{2}}{2 \boldsymbol{R}}$

So by replacing the absorption coefficient $\alpha$ in the Tauc's equation get

$(\alpha \cdot h v)=A\left(h v-E_{g}\right)^{n}$

From equation (2) it was got

$\alpha=\frac{\mathbf{A}(\mathbf{h} \mathbf{v}-\mathbf{E g})^{n}}{\mathbf{h v}}$ 


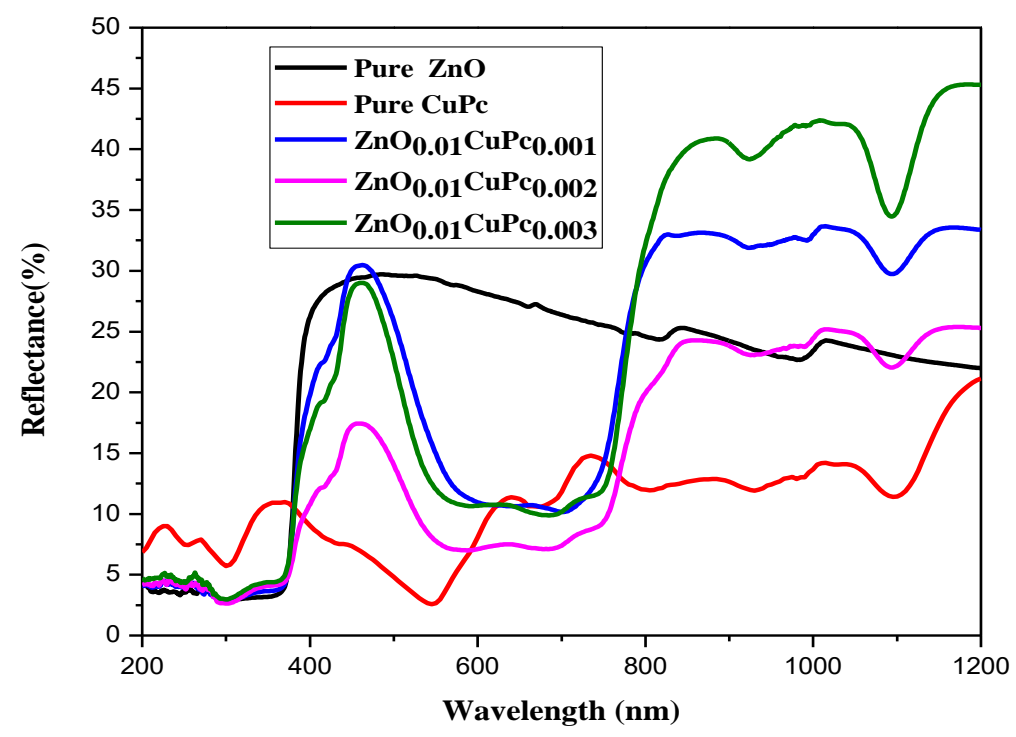

Figure 1. Reflectance spectra for pure $\mathrm{ZnO}$, pure $\mathrm{CuPc}$ and doping $\mathrm{ZnO}$ with $\mathrm{CuPc}$ composites.

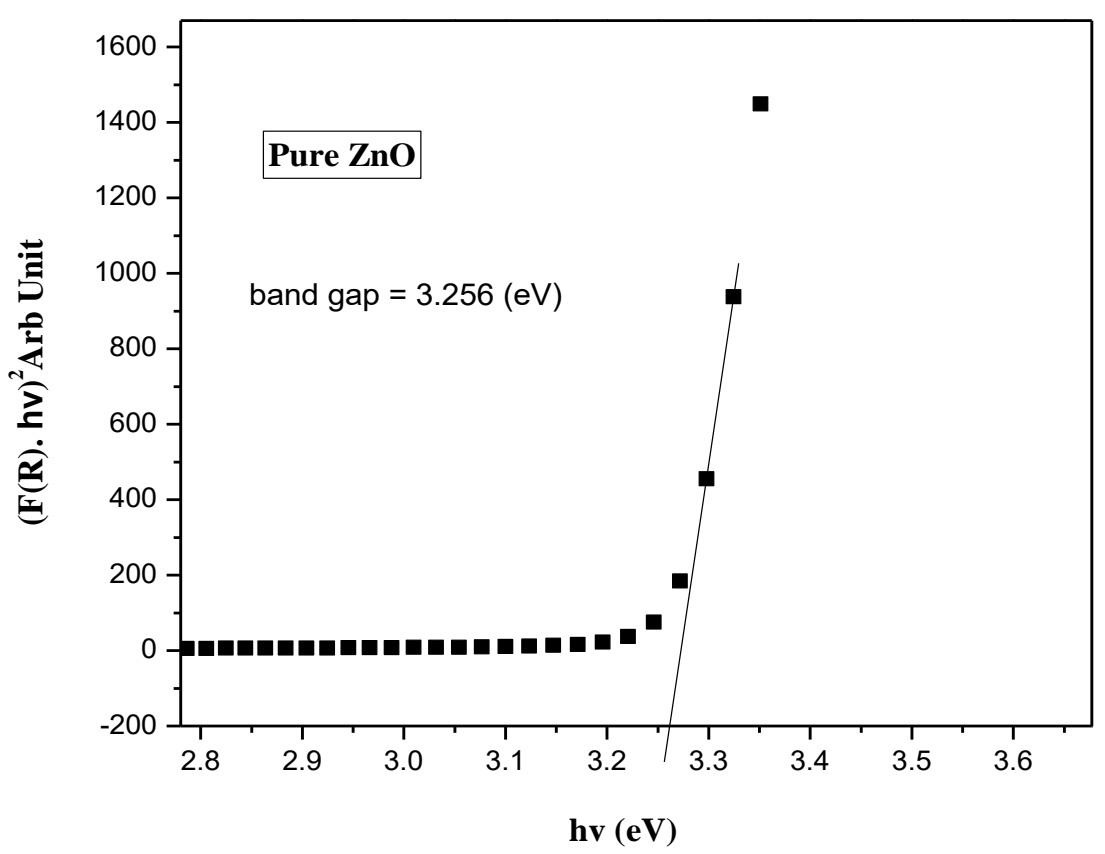

Figure 2. Band gap energy for pure $\mathrm{ZnO}$ Nano composite.

In equation (3) Where $\mathrm{h} v$ is the energy of incident photons and $\mathrm{A}$ is a constant. $\alpha$ is the absorption coefficient, exponents $\mathrm{n}$ whose value depends upon the type the transition. They may have values $1 / 2,2,3 / 2$ and 3 . That values indicate to forbidden direct and indirect transitions, the allowed direct and indirect. For the direct band gap, the draw between $(F(R) . h v) 2$ and photon energy $(\mathrm{h} v)$ has been shown in Fig $(2,3)$ with $n$ values of $1 / 2$. The band gap energy value could be determined by extrapolating the plot of the linear region of the plot to an energy 
axis at $(\mathrm{F}(\mathrm{R}) \cdot \mathrm{h} v) 2=0$, it was found the band gap energy for pure $\mathrm{ZnO}$ is equal to $3.256(\mathrm{eV})$, but the standard value of band gap energy for pure $\mathrm{ZnO}$ is equal to $3.37(\mathrm{eV})$ and the standard value energy of band gap for pure $\mathrm{CuPc}$ is equal to $3.02(\mathrm{eV})$, then if the mass of $\mathrm{ZnO}$ stay constant, small increase the mass of $\mathrm{CuPc}$, it was seen the value band gap decrease because the value band gap for $\mathrm{ZnO}$ bigger then $\mathrm{CuPc}$, then the band gap for sample $\mathrm{ZnO} 0.01 \mathrm{CuPc} 0.001$ is equal to be $2.029(\mathrm{eV})$, for sample $\mathrm{ZnO} 0.01 \mathrm{CuPc} 0.002$ band gap energy is equal to $2.203(\mathrm{eV})$, and for sample $\mathrm{ZnO} 0.01 \mathrm{CuPu} 0.003$ the value band gap energy is equal to $2.112(\mathrm{eV})$.

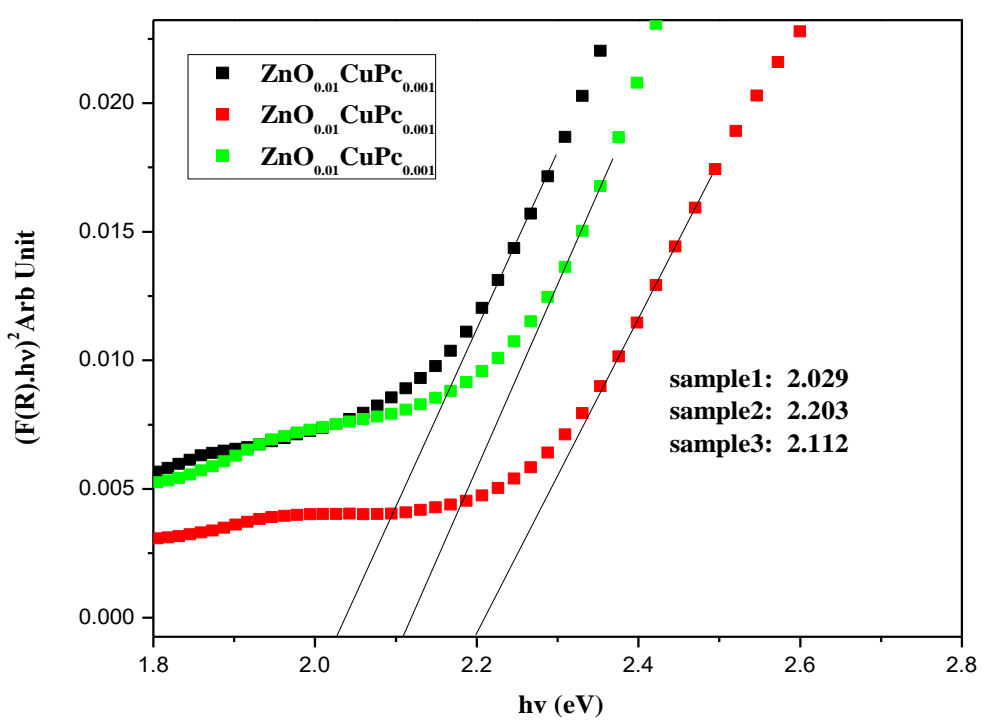

Figure 3. Band gap energy for doping $\mathrm{ZnO}$ and $\mathrm{CuPc}$ Nano composite.

\subsection{Electrical Conductivity}

Electrical conductivity is known as the amount of electrical current measurement which material could transport or its ability to bear a current. Specific conductance is also known as electrical conductivity. Conductivity is a base property of a material [19].

In order to research the electrical properties of the samples, the dc conductivity of the sample was measured by the I-V graph. The (I-V) graph for four samples has been displayed in Fig. 4. (a-d). The electrical conductivity ratios were found for four samples by this equation

$\sigma=\frac{I}{V} \times \frac{\boldsymbol{l}}{\boldsymbol{A}}$

In this equation $\sigma$, the electrical conductivity and $\frac{I}{V}$ is equal slope, (1) is contact distance and (A) the surface area. Using the defined slope, distance and area electrical conductivity can be found. The electrical conductivity for sample Pure $\mathrm{ZnO} 0.01$ was found is equal to $0.586 \times 10-8 \mathrm{~S} / \mathrm{cm}$, for $\mathrm{ZnO} 0.01 \mathrm{CuPc} 0.001$ is equal to $0.55 \times 10-8 \mathrm{~S} / \mathrm{cm}$, for $\mathrm{ZnO} 0.01 \mathrm{CuPc} 0.002$ is equal to $0.47 \times 10-8 \mathrm{~S} / \mathrm{cm}$, for $\mathrm{ZnO} 0.01 \mathrm{CuPc} 0.003$ is equal to $0.58 \times 10-8 \mathrm{~S} / \mathrm{cm}$. It can be clearly seen from the graphs below that the conductivity is decreasing with the increase of CuPc. 

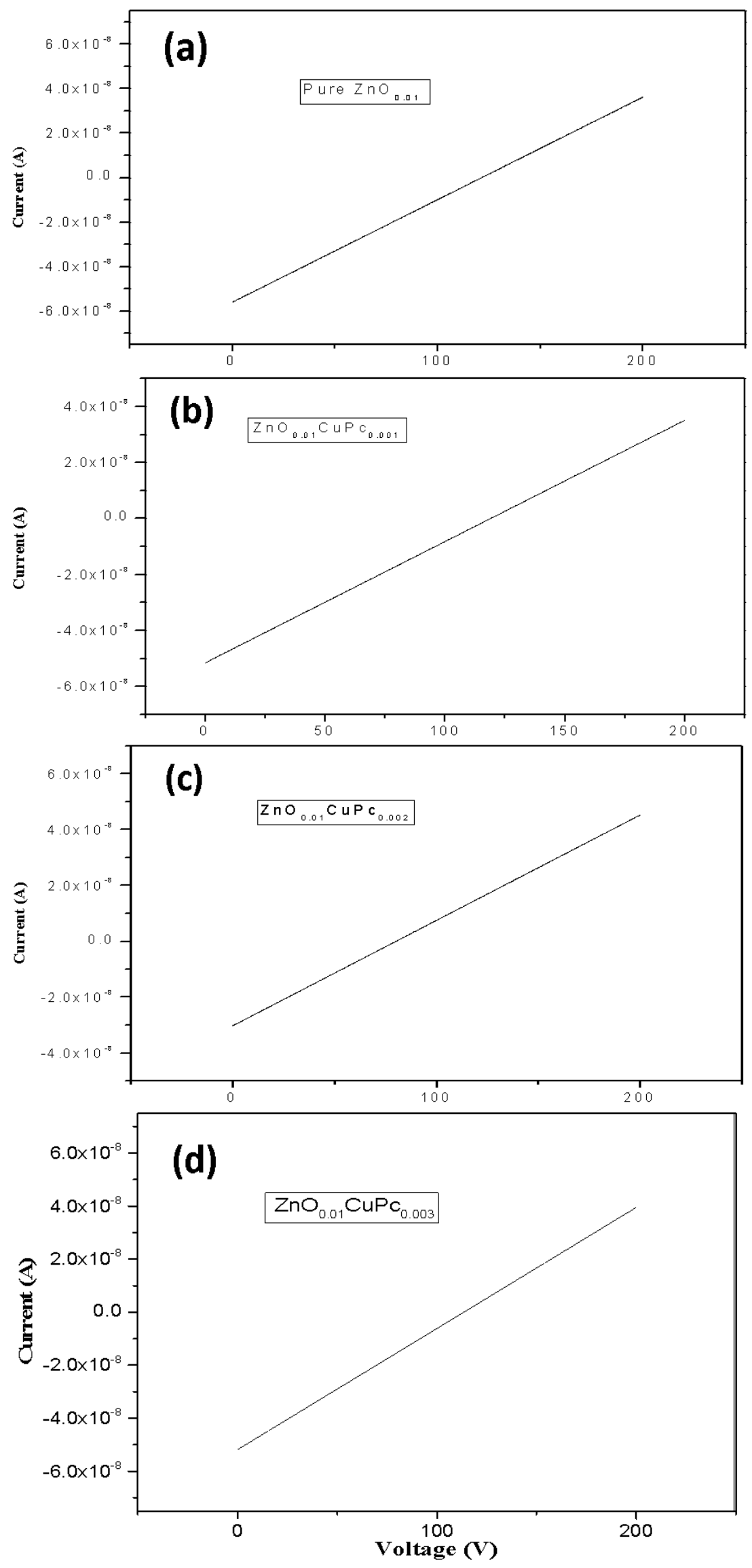

Figure 4. $\mathrm{DC}$ conductivity for pure $\mathrm{ZnO}$ and doped with $\mathrm{CuPc}$ (a) pure $\mathrm{ZnO}$ (b) $\mathrm{ZnO} 0.01 \mathrm{CuPc} 0.001$ (c)

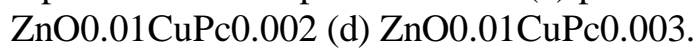




\section{CONCLUSION}

$\mathrm{ZnO}$ were synthesized by using the hydrothermal technique then doped with $\mathrm{CuPc}$ to make a composite. The optical properties of materials investigated by using Tauc's equation. The estimated optical band gap for pure $\mathrm{ZnO}$ were $(3.256 \mathrm{eV})$ and for doped $\mathrm{CuPc}$ were decreased to $(2.029(\mathrm{eV}), 2.203(\mathrm{eV}), 2.112(\mathrm{eV}))$ respectively. The electrical conductivity was measured for pure $\mathrm{ZnO}$ and composites. Significant shifts have been detected and it was seen that the taken measurements are in a good agreement with literature.

\section{Acknowledgements}

This work is financially supported by FÜBAP, Project No: FF.16.33

\section{References}

[1] P. Ayyub, V. Palkar, S. Chattopadhyay and M. Multani, Physical Review B, 51 (9) (1995) 6135.

[2] M. Fernandez-Garcia, A. Martinez-Arias, J. Hanson and J. Rodriguez, Chemical Reviews, 104 (9) (2004) 4063-4104.

[3] H. Gleiter, Nanostructured materials, 6 (1-4) (1995) 3-14.

[4] M. S. Tokumoto, S. H. Pulcinelli, C. V. Santilli and V. Briois, The Journal of Physical Chemistry B, 107 (2) (2003) 568-574.

[5] A. Aimable, B. Xin, N. Millot and D. Aymes, Journal of Solid State Chemistry, 181 (1) (2008) 183-189.

[6] J. McHale, A. Auroux, A. Perrotta and A. Navrotsky, Science, 277 (5327) (1997) 788-791.

[7] H. Zhang and J. F. Banfield, Chemistry of materials, 17 (13) (2005) 3421-3425.

[8] M. D. Hernández-Alonso, A. B. Hungría, A. Martínez-Arias, J. M. Coronado, J. C. Conesa, J. Soria and M. Fernández-García, Physical Chemistry Chemical Physics, 6 (13) (2004) 3524-3529.

[9] R. Cammarata and K. Sieradzki, Physical review letters, 62 (17) (1989) 2005.

[10] M. Fernández-García, X. Wang, C. Belver, A. Iglesias-Juez, J. C. Hanson and J. A. Rodriguez, Chemistry of materials, 17 (16) (2005) 4181-4193.

[11] J. Hasnidawani, H. Azlina, H. Norita, N. Bonnia, S. Ratim and E. Ali, Procedia Chemistry, 19 (2016) 211-216.

[12] M. El-Nahass, Z. El-Gohary and H. Soliman, Optics \& Laser Technology, 35 (7) (2003) 523-531.

[13] E. Jungyoon, S. Kim, E. Lim, K. Lee, D. Cha and B. Friedman, Applied Surface Science, 205 (1-4) (2003) 274-279.

[14] E. Orti, J. Bredas and C. Clarisse, The Journal of chemical physics, 92 (2) (1990) 12281235.

[15] J. Puigdollers, C. Voz, M. Fonrodona, S. Cheylan, M. Stella, J. Andreu, M. Vetter and R. Alcubilla, Journal of Non-Crystalline Solids, 352 (9-20) (2006) 1778-1782. 
[16] Z. Bao, A. J. Lovinger and A. Dodabalapur, Applied Physics Letters, 69 (20) (1996) 30663068 .

[17] K. Xiao, Y. Liu, G. Yu and D. Zhu, Synthetic metals, 1 (137) (2003) 991-992.

[18] S. Martellucci, A. N. Chester and A. G. Mignani, Optical sensors and microsystems, (Springer, 2002) 3-315.

[19] R. Hamad, Production and characterization of the metal oxide - organo metalic composites by hydrothermal method, (The Graduate School of Natural and Applied Science, Frrat University, Elazığ, Turkey, 2017) 1-67. 